Portland State University

PDXScholar

3-15-2017

Peruvian Food: the Social and Cultural Origins of Peruvian Food

Kari Hatlestad

Portland State University

Follow this and additional works at: https://pdxscholar.library.pdx.edu/honorstheses Let us know how access to this document benefits you.

Recommended Citation

Hatlestad, Kari, "Peruvian Food: the Social and Cultural Origins of Peruvian Food" (2017). University Honors Theses. Paper 367.

https://doi.org/10.15760/honors.360

This Thesis is brought to you for free and open access. It has been accepted for inclusion in University Honors Theses by an authorized administrator of PDXScholar. Please contact us if we can make this document more accessible: pdxscholar@pdx.edu. 
Running Head: THE SOCIAL AND CULTURAL ORIGINS OF PERUVIAN FOOD

\title{
Peruvian Food:
}

\section{The Social and Cultural Origins of Peruvian Food}

\author{
By \\ Kari Hatlestad \\ An undergraduate honors thesis submitted in partial fulfillment of the \\ requirements for the degree of \\ Bachelor of Arts \\ in \\ University Honors \\ and \\ International Development - Latin America
}

Thesis Advisor:

Leopoldo Rodriguez

Portland State University

2017 


\begin{abstract}
Dating back 20,000 years ago, a majority Peru's cuisine consisted of potatoes and legumes, native plants, and grains. Over time, Peru's cuisine evolved through the fusion of indigenous Peruvian cultures, Spanish colonization, Arab/Moorish influences, the arrival of slaves from Africa, and Japanese and Chinese immigrants. This historical integration led to a unique food cultures and cuisines including "Creole", "Nikkei" and "Chifa". This thesis reviews the agricultural practices, culinary techniques, and melding of foods that gave birth to what we now know as Peruvian cuisine. As examples of this amalgamation, I have chosen six recipes for analysis - Pisco Sour, Ceviche, Pachamanca, Aji de Gallina, Chaufa, and Cuy, to show how historical and cultural elements give rise the flavors of Peruvian cuisine.
\end{abstract}




\section{Table of Contents}

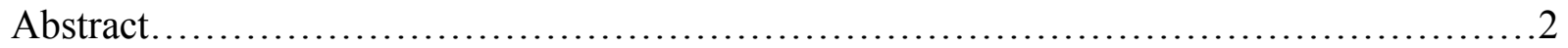

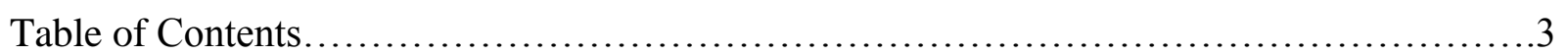

Acknowledgments $\ldots \ldots \ldots \ldots \ldots \ldots \ldots \ldots \ldots \ldots \ldots \ldots \ldots \ldots \ldots \ldots \ldots \ldots \ldots \ldots \ldots \ldots \ldots \ldots \ldots \ldots \ldots .4$

Chapter I. Introduction....................................................... 5

Chapter II. The Multiple Origins of Peruvian Cuisine........................................ 6-16

Incan/Moche tribes............................................................. 6

Spanish Colonization...................................................... 9-10

African Slave Trade/ Moorish Influence................................... 10-12

Japanese/ Chinese Migration........................................... 12-14

The Cookbooks/Recipes.............................................. 14-15

Chapter III. The Sociocultural Roots of Six Peruvian Recipes......................... 16

Pisco Sour.......................................................... 16-17

Ceviche............................................................ 18-19

Pachamanca........................................................ 20 21

Aji de Gallina....................................................... 22-23

Chaufa.............................................................. 24-25

Cuy............................................................... 26-27

Chapter IV. Conclusions .................................................... 28

References............................................................. 29-30 


\section{Acknowledgements}

I first would like to thank my friends, family, and partner for encouraging me to study my passions and interests. In addition, I would like to thank my sister for traveling with me through South America and help me interview the people who motivated this study. Lastly, I would like to thank my advisor, Leopoldo Rodriguez for mentoring me through my study abroad semester and during my research. Thank you, all. 


\section{Chapter I. Introduction}

"Without food there would be no human race, and no history. For 50,000 years and more, humanity's quest for food has helped to shape the development of society"

-Reah Tannahill (1973)

When one enters a country they almost immediately encounter food. The tastes, the smells, the sight of fresh fruit or meats lined along the street define the country's cuisine. It is natural to assume that the dishes served in restaurants or made in our grandmother's kitchen are authentic to that place - the origin of the dish. However, how original can a country's cuisine be now with centuries of globalization; both physical and technological? Most dishes have their origins in the fusion of elements from many countries around the world as thoughts, ideas, and cultures merged together. This research uncovers the cultural and historical origins of Peruvian food with reference to specific dishes. Their roots stir together a movement of ingredients, culinary techniques, and agricultural development to create what is now known as Peruvian cuisine.

In this thesis I will explore the social and cultural origins of Peruvian food exploring the influences bearing in Peru's history and using the recipes and ingredients involved in making six distinctive dishes. I will rely on secondary sources, mostly history books and cookbooks. The majority of cookbooks I will use were written by Peruvian chefs that have studied the ancestry of Peruvian ingredients. These cookbooks provide the recipes for the six dishes I will analyze in greater detail, namely Pisco Sour, Ceviche, Pachamanca, Aji de Gallina, Chaufa, and Cuy. 


\section{Chapter II. The Multiple Origins of Peruvian Cuisine}

As Tannahill (1973) expresses, much of human life revolves around one of the key points of survival - food. For millenia, societies have transitioned, been manipulated, migrated, and developed influencing the food set on our plates. We start with a review of historical sources to explore the melding of cultures in Peru. We then move to the analysis of recipes from multiple cookbooks, selecting Pisco Sour, Ceviche, Pachamanca, Chaufa, Aji de Gallina, and Cuy as the six dishes for deeper research. Using a variety of cookbooks allows us to compare and contrast the ingredients used, culinary techniques, and the historical context manifested by the recipe.

Peruvian food is often described as a metaphoric stew simmering for generations and now ready to be served. Rex Hudson (1993) investigated pre-colonial Peru. At the beginning stages of our stew, Peru was settled by various indigenous cultures spread across a number of geographic regions. The coast, mountains, and jungle segregated native Peruvians into separate communities and eventually empires. Hudson (1993) first discusses cultures dating 20,000 years ago, the descendants of original migrants who crossed the "land bridge" over what we know as the Bering Straits between the Asian and American continents. Over the next several millennia hunters and gatherers' dominated parts of Peru and surrounding countries (Hudson, 1993). Around $2500 \mathrm{BC}$ small communities began to develop in fertile river valleys of the northern coast of Peru (Hudson, 1993). Archeological research has found evidence of middens around 8000 BCE near the coastal regions of Peru (Peterson \& Soltvedt, 2006). Coastal middens are layers of shell exposed in the sides of dunes, banks, or eroded surfaces (Oxford English Dictionary). This suggests the diet of early coastal cultures included shellfish, fish, chili peppers, squash, sweet potatoes, various tubers, beans, gourds and pacae (a huge, boomerang-shaped 
legume) (Peterson \& Soltvedt, 2006). Trading in the highland and coastal groups was already taking place prior to the second millennium BCE as evidence by the presence of non-native foods in the deposits: marine fish and shellfish in some highland middens and indigenous highland tubers in some coastal middens (Peterson \& Soltvedt, 2006). The majority of evidence found from agriculture production during that era has a diet of coastal cultures including shellfish, fish, chili peppers, squash, sweet potatoes, various tubers, beans, gourds, guava, and lúcuma (Peterson \& Soltvedt, 2006). Meanwhile, early human occupation has been found in the Pachamachay cave located 14,000ft. above sea level near Lake Junín (Peterson \& Soltvedt, 2006). In this cave, human occupancy has been found from about "7000 BCE to 1500 BCE" (Peterson \& Soltvedt, 2006, p. 3). Because of the altitude in this area, agriculture production was limited, but included small grains such as quinoa, tubers, legumes, and a variety of prickly pear cactus (Peterson \& Soltvedt, 2006). Moving closer to sea level towards the tropical jungle other crops, such as "peanuts, sweet potatoes, yucca, and coca" were produced (Peterson \& Soltvedt, 2006, p. 3). There is also indication of trade between regions. Evidence from ceramic remains and housing structures provide information about their food traditions. In some regions, kitchens contained pens for guinea pigs (Peterson \& Soltvedt, 2006).

By the early first to the eighth century AD, the Moche Empire flourished in northern Peru. The Inca Empire, which spoke Quechua, dominated the coast of northern and central South America from the $13^{\text {th }}$ century until conquered by the Spanish in the late $16^{\text {th }}$ century (Hudson, 1993). The Mochica Empire had emerged in the $1^{\text {st }}$ century. They were commonly known for their impressive ceramics. A majority of its inhabitants lived near the northern coast and inland valleys leading to a high consumption of seafood and plants. Agriculture developed mostly in river valleys (Peterson \& Soltvedt, 2006), where an irrigation system was created linking several 
river valleys together (Peterson \& Soltvedt, 2006). Mochica pottery depicts rituals with people partaking of coca, a plant grown on the slopes of inland valleys and obtained by the Moche in trade from Amazonian communities (Peterson \& Soltvedt, 2006). Other scenes depict the preparation and consumption of corn beer, which was a common beverage during Moche society rituals (Hudson, 1993). The Mochica civilization collapsed by the 8th century due to unknown reasons, but possible factors include earthquakes, prolonged drought, catastrophic flooding, the encroachment of sand dunes on populated areas, or less-tangible social and cultural factors (Hudson, 1993).

The Inca established their capital at Cuzco (Peru) in the 12th century (Hudson, 1993). They began their conquests in the early 15 th century and within 100 years had gained control of an Andean population of about 12 million people (Hudson, 1993). In common with other Andean cultures, the Inca left no written records (Hudson, 1993). Their history is known chiefly from the oral tradition that has been preserved through the generations by official "memorizers" and from the written records composed from them after the Spanish conquest (Hudson, 1993, p. 22). Mostly settled higher in the Andes, the Incans obtained agricultural skills growing a variety of grains, potatoes, tubers, and legumes on slopes (Hudson, 1993). Using terraces for cultivation, they adapted watercourses for irrigation of their crops. Many of their agricultural techniques continue to be practiced to this day (Hudson, 1993). Hudson (1993) claims the Incas had a technique called "vertical complementarity" the ability to produce a wide variety of crops such as maize, potatoes, and quinoa, at different altitudes. The indigenous peoples of the Inca Empire believed that Pachamama (mother nature) provided them with all their food (Cuadra \& Escardó, 2014). They mastered the food preservation crafts of smoking, drying, and salting food. One technique in particular involved storing their meats and vegetables high on the slopes of the 
Andes Mountains in Peru (Hartel \& Hartel, 2008). The cold temperatures froze the food and the low atmospheric pressures at the high altitudes dried the food out (Hartel \& Hartel, 2008). Thanks to their advanced understanding of agriculture and innovative technologies, food in this empire was bountiful (Cuadra \& Escardó, 2014). Inca Empire expansion was slow and moved "along the Andean spine" (Hudson, 1993, p.12), but came to a sudden stop in the mid 15th century with the Spanish conquest.

According to Hemming (1970) the Spanish conquest of the Inca Empire was one of the most important campaigns in the colonization of the Americas (Hemming, 1970). After years of preliminary exploration and military skirmishes, 180 Spanish soldiers under conquistador Francisco Pizarro, his brothers, and their native allies captured the Sapa Inca Atahualpa in the 1532 Battle of Cajamarca (Hemming, 1970). Hemming (1970) includes that the conquest was the first step in a long campaign that took decades of fighting but ended in Spanish victory in 1572 and colonization of the region as the Viceroyalty of Peru. The Spanish brought over Catholicism, diseases, slaves, food imports, and more (Hemming, 1970). This colonial insertion dramatically impacted the Peruvian diet into what Acurio (2015) has defined as the "creole cuisine" (Acurio, 2015). A few food commodities that accompanied Spanish voyages include - pigs, cattle, sheep, goats, donkeys, horses, chicken, cheese, butter, wheat, rice, barley, onions, garlic, chickpeas, lentils, olives, citrus fruits, sugar cane, olive oil, and wine. (Peterson \& Soltvedt, 2006). These commodities were not found on the South America continent prior to the arrival of the Spanish. However, they are now staples of the diets and agro-economy of the subcontinent.

Meanwhile, before the colonization of Peru, Spain had been introduced to many cuisines around the world including cultural contributions from the Moors that occupied Spain through 
the $8^{\text {th }}$ through $15^{\text {th }}$ centuries (Fletcher, 2006). The Moors were Muslim inhabitants of "Maghreb, North Africa, the Iberian Peninsula, Sicily, and Malta" (Fletcher, 2006, p. 1). The Spanish occupation by the Moors began in 711 AD when an African army, under their leader Tariq ibnZiyad, crossed the Strait of Gibraltar from Northern Africa and invaded the Iberian Peninsula 'Andalus' (Spain under the Visigoths) (Fletcher, 2006). The forces here were swiftly followed by reinforcements so that, within 7 years, the Muslim conquerors, who came to be known as The Moors, were in control of most of the Peninsula - a situation that was to remain more or less intact for the next 400 years - but, in some parts, for the next 700. Initially, Islamic Spain known as Al-Andalus - formed a part of the North African province controlled by Damascus, the capital of the Islamic world (Fletcher, 2006). Internal divisions within the ruling Umayyad family, however, led to Abd-al-Rahman fleeing Syria in 756 and establishing an independent emirate in Córdoba (Fletcher, 2006). This led to a dynasty that united Muslim Spain, centralized the power in Córdoba and resulted in Córdoba becoming one of the biggest and most important cities in Europe (Fletcher, 2006).

After Seville fell to the Christians in 1248, the only Muslim territory remaining was the Emirate of Granada, which consisted of about half of modern Andalucía (Fletcher, 2006). Granada was thus the site of Moorish Spain's final, flamboyant cultural flowering, helped by the refugees fleeing from former Muslim strongholds (Fletcher, 2006). Muslims maintained control of Granada until 1492, when the northern kingdoms of Castile, Aragón, León, Navarra and Asturias united and conquered the kingdom - ending centuries of Muslim rule in Spain (Fletcher, 2006). The Muslims, though, left a lasting legacy for Spain - they did not simply occupy the country; they also contributed to a great history and contribution to Spanish cultures. Obviously the great palaces, castle and mosques of Moorish times are amongst Spain's greatest tourist 
attractions - and rightly so - but also they also contributed to many foods that are still consistently used in Spain today. For example, pomegranates, oranges, lemons, eggplant, artichokes, cumin, coriander, bananas, almonds, saffron, sugar-cane, cotton, rice, figs, grapes, peaches and apricots were all introduced by the Moors (Fletcher, 2006). So too were the irrigation systems that enabled the dry plains to be efficiently farmed, the narrow, labyrinthine street plans of many of the old towns and even the flamenco itself has clear Islamic origins (Fletcher, 2006). Meanwhile, Peschiera (2005) explains how some of these ingredients transitioned to Spanish making its mark on Peruvian dishes closer to the $16^{\text {th }}$ century. Peschiera (2005) states, "New food items included olives and olive oil, wheat and its derivatives: fruits such as oranges, pears, figs, limes, apples...(p.9). The list goes on of ingredients that all influenced and created Peruvian dishes.

An important piece of Peruvian cuisine wasn't only the Arab-Moorish to Spain, but Spain's history with Africa. Spain brought African slaves to Peru starting in 1521 (Lockhart, 1994). They worked mainly on roads and bridges developing the infrastructure of the colony one day at a time. There were two main types of slaves, one native-born in Africa referred to as "bozales" (unskilled) who were shipped from Africa (Lockhart, 1994, p. 193). The second type were Afro-Peruvians, born in the colonies and acculturated to Spanish culture and who spoke Spanish whom some were mixed-race, descendants of Spanish men and African women (Lockhart, 1994, p. 193). People of color performed skilled and unskilled functions that contributed to Hispanic colonization (Lockhart, 1994). African slaves were primarily used for their labor in South American colonies. Slaves tended large gardens and households providing food for local consumption (Peterson \& Soltvedt, 2006). In addition, slaves played a vital role in mining and the wine industry (Peterson \& Soltvedt, 2006). The culinary contribution from 
people of African origin led to dishes such as "pieces of beef heart or other organ varieties, and fish marinated in spicy sauce with red chili peppers and grilled on skewers" (Peterson \& Soltvedt, 2006, p. 14). African and Arab-Moorish cultures had an influence in the creation of recipes such as Aji de Gallina and multiple stews (Acurio, 2015, p. 11). Another dish of African origin is a popular dessert created by a former slave in gratitude of the Lord of Miracles for healing her "lame leg" is a treat made with three thick slabs of anise-flavored shortbread stuck together with honey or syrup with candies sprinkled on top (Peterson \& Soltvedt, 2006, p. 14) Another significant influence on Peru's cuisine resulted from the Japanese and Chinese immigration of the late $18^{\text {th }}$ and early $19^{\text {th }}$ centuries. One reason this integration is interesting to Peru's cuisine is because it had a significant timeline gap in comparison to Spanish colonization and Arab/Moorish and African slavery, which took place during the $15^{\text {th }}$ and $16^{\text {th }}$ centuries. The Japanese began arriving in Peru in the late 1800s. Many factors motivated the Japanese to immigrate to Peru. At the end of the $19^{\text {th }}$ century, a rumor spread in Japan that a country called Peru had piles of gold (Takenaka, 2004). A paradise with temperate weather and rich soil for farming interested many Japanese migrants (Takenaka, 2004). A majority of immigrants left from Okinawa with passion for new land, nice weather, farming, and labor (Takenaka, 2004). Peruvians of Japanese descent, though constituting only 0.3 percent of Peru's population, were brought to the world's attention by the election of Alberto Fujimori, the son of Japanese immigrants, as president, and arguably one of the country's most influential ethnic communities both economically and politically (Takenaka, 2004). The Japanese community in Peru, remains an ethnic minority and is somewhat insulated (Takenaka, 2004). As for agricultural practices, a majority of the Chinese and Japanese settled near the coastal region of Peru (Zarate, 2015). Many of them worked on sugar and cotton plantations (Zarate, 2015). Culinary techniques and 
culture fusion from Asian influence included many "stir-fries, sautés, and use of raw fish" (Zarate, 2015 p. 10). As a result, the most recent and significant integration to Peru is the Japanese and Chinese immigration. This caused the cuisine to take a turn from Japanese and Chinese restaurants opening to stir-frying dishes and eating raw fish. Acurio (2015) explains the melding of Japanese and Peruvian cultures gave birth to a new cuisine called "Nikkei".

Furthermore, the Japanese love of seafood helped incorporate dishes such as octopus and olive oil, ceviche's, and various noodle with seafood dishes helped create the Nikkei (Japanese and Peruvian) cuisine (Acurio, 2015, p.11). Additionally, Chinese migrants also arrived during the $19^{\text {th }}$ century as migrant workers bringing customs and recipes with them. "Chifa" or ChinesePeruvian cuisine introduced techniques such as sautéing over a high flame, adding soy sauce to stir-fries, and eating white rice with almost every meal (Acurio, 2015, p .11). This shows that Peru has been a melting pot of multiple countries and cultures, giving rise to a "Creole" cuisine (Spanish/African/Arab fusion), "Nikkei" cuisine (Japanese fusion), and "Chifa" cuisine (Chinese fusion).

In Acurio's (2015) cookbook, Peru, he provides a brief description of the historical influences on regional Peruvian foods. This cookbook will be the primary reference for four recipes of the six recipes to be illustrated below (Traditional Ceviche, Pisco Sours, Pachamanca, and Chaufa) including ingredients used, cooking instructions, and the regions of Peru where they are commonly found. These recipes are also found in his earlier book, 500 años de fusion: la historia, los ingredients, y las nuevas propuestas de la cocina peruana, which has additional description of the origins of ingredients used. For example, Peruvian ceviche contains six simple ingredients including: white fish (such as sole), garlic, fresh lime juice, cilantro, and red onion. 
During the $16^{\text {th }}$ century, Spain brought citrus trees to Peru. In addition to Acurio's (2009) historical context on the ingredients,

Cuadra and Escardó (2014) wrote a history of Peruvian food, as it is known today describing it as a fusion of "Incan roots, mixed with Spanish, Arab, African, Chinese, Italian, Japanese, and French influences" (p. 5-6). Below we will discuss two recipes from Cuadra and Escardó (2014): Ceviche and the Pisco Sour. Cuadra and Escardó (2014) use a similar style Glossary as Acurio (2015) showing the ingredients included in the recipes with a background on the region where it is commonly found, and characteristics of the ingredient. For example, aji aramarillo, is a common Peruvian pepper used in many Peruvian dishes, sometimes added to top ceviche with a little spice. This pepper is native to the Andes (2014, p.248). It has a crisp texture with orange and yellow hues.

Emilio Peschiera (2005) discusses the history and evolution of Peruvian cuisine, from its beginnings with the Incas to its latest international success, including a review of some basic techniques for preparing recipes with Peruvian flavors. Peschiera (2005) also explores various ingredients and their purpose for within the dishes. He provides time periods when ingredients were imported from other countries contributing to regional plates as Preuvian cuisine made its name. From this book we will discuss the recipes for Chaufa and Aji de Gallina. Peschiera (2005) also includes a Glossary explaining the ingredients and explains fusions similar to those found in the other two cookbooks. Peschiera (2005) additionally includes foods that were commonly brought to Peru from abroad. I will use this information to discuss the ingredients of the six Peruvian dishes I chose to examine in detail. For example, Peschiera (2005) explains how Spanish influence also included influence from the Moors, who had occupied Spain from the $8^{\text {th }}$ to the $15^{\text {th }}$ centuries. Spanish cuisine made its' mark on Peruvian dishes closer to the $16^{\text {th }}$ 
century. Peschiera (2005) states, "New food items included olives and olive oil, wheat and its derivatives: fruits such as oranges, pears, figs, limes, apples...(p.9). The list goes on of ingredients that all influenced and created Peruvian dishes. Aji de Gallina, for example, uses olives to top the yellow sauce poured over chicken and rice. Olives were brought over from Spain (Peschiera, 2005).

Joan Peterson and Brook Soltvedt (2006) provide ingredients and dishes, along with an intensive background of the historical influence. They explain the background of one of the recipes I will analyse. Cuy translates to guinea pig. It is a rodent common in the Andes, where guinea pigs run wild (Peterson \& Soltvedt 2006). Cuy became a common dish for Peru, as they became domesticated and raised for meat just as one would for rabbit, lamb, pig, etc. Peterson \& Soltvedt (2006) also include variations of ingredients provided other recipes such as pachamanca, various types of ceviche's, sauces, and more.

Mirko and Vera Lauer (2006), introduce a history of tastes, color, preparation, and culture in Peruvian food. They explore its history and social and cultural movement. The book provides chapters discussing the origins of Peruvian food, immersion of Peruvian cooking, Peruvian plates shared around the world, and how globalized food has impacted Peru's traditional cuisine. While their book can be difficult to translate from Spanish, it is helpful to read a book written in Peru about their traditional food. Mirko Lauer and Vera Lauer's (2006) provide a timeline of the most common food found in Peru and describe one of my chosen dishes, ceviche. This dish came from a few different sources, such as limes originating in Spain and the eating of raw fish came from Japan (2006, p. 30). 


\section{Chapter III. The Sociocultural Roots of Six Peruvian Recipes}

Pisco Sour (Acurio, 2015, p. 396)

Serves: 1

Preparation Time: 5 minutes

\section{Ingredients:}

15 ice cubes

6 tablespoons Quebranta pisco

2 tablespoons lemon juice

2 tablespoons sugar syrup

1-tablespoon egg white

2 drops Angostura bitters, to

finish

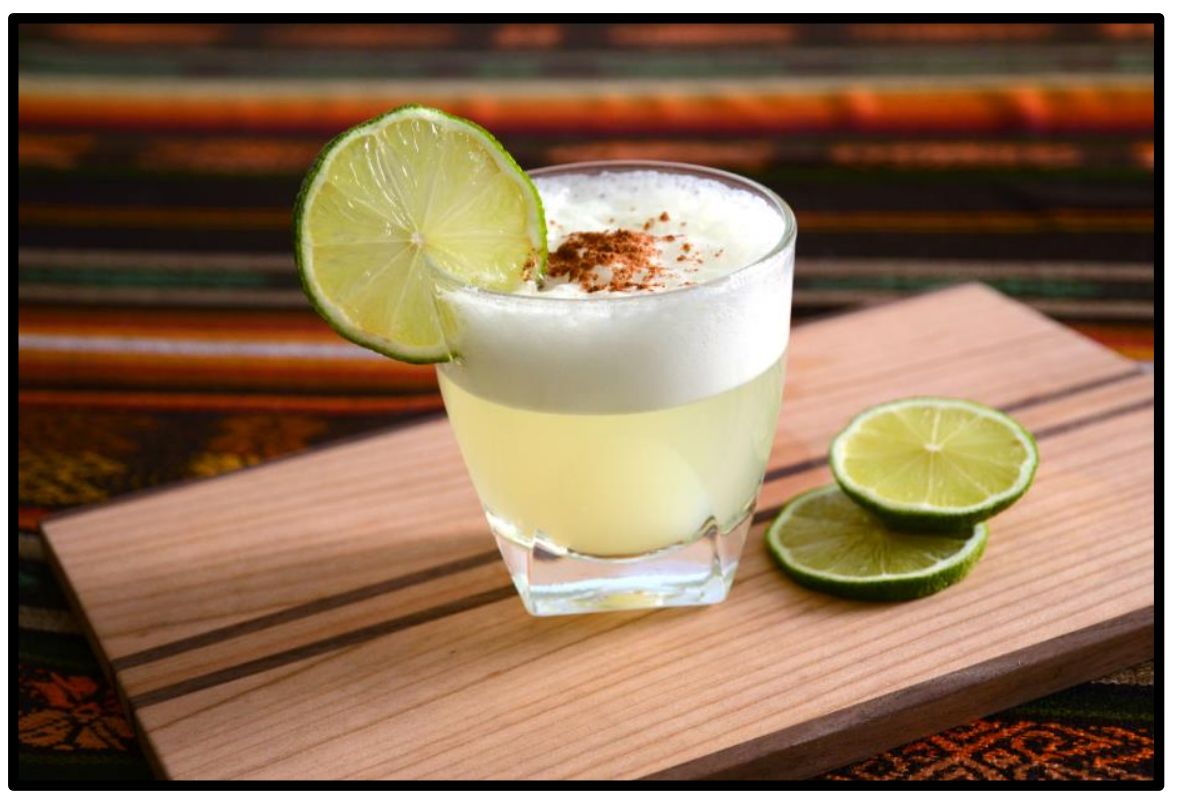

Figure 1: Pisco Sour (Montgomery, 2014)

\section{Preparation:}

Place the ice in a blender or cocktail shaker and pour in liquid ingredients. Blend for 3 seconds or shake for 8, then strain into a chilled stemless cocktail glass. Drop the Angostura bitters in the center of the drink to finish

\section{About the Ingredients:}

The Pisco Sour was created by an expat American named Victor V (Montgomery, 2014). Morris who traveled to Lima, Peru in the early-20th century opened a saloon (Montgomery, 2014). A variation on the "Whiskey Sour, Morris supposedly first mixed his version using the native spirit on July 28, 1904" (Montgomery, 2014). Of course, as with the Daiquiri, attributing the origination of a relatively simple cocktail to just one person at one particular time is problematic (Montgomery, 2014). If nothing else, Morris was a significant figure in the standardization and popularization of the Pisco Sour, and for that, he certainly deserves praise (Montgomery, 2014). 
Pisco is a common alcohol made from grapes. The name pisco came from Piskos (or Pishkos) from the caste of potters that made giant clay jars the Spanish used for Botija olives, and later wine and grape infused spirits, such as pisco (Zarate, 2015, p. 230). Before the spirit became official, other names were known such as grape firewater or aguardiente, which is a generic term for moonshine in some Latin countries (Zarate, 2015). Pisco finally derived its name from the Port of Ica, the main grape growing region south of Lima, became the main portal where the grape spirit was exported around the world (Zarate, 2015). Now known as the Port of Pisco. The other main ingredient in a pisco sour is lemon, or some other recipes call for limes. According to Acurio (2015) the Spanish brought over a majority of citrus fruits including limes and lemons. However, it is possible there were come varieties of citrus fruits in the Amazon before colonization, but the Pisco sour developed further as the Spanish helped develop grape vineyards and pisco distilleries. 


\section{Ceviche Clásico (Acurio, 2015, p. 16)}

Serves: 4

Preparation Time: 10 minutes

\section{Ingredients:}

$4 \times 6 \mathrm{oz}$ white fish fillets (such as sole, croaker, or grouper)

2 cloves garlic, finely chopped

2 teaspoons limo chili, chopped juice of 20 small lemons

1 teaspoon chopped cilantro leaves 2 or 3 ice cubes

1 red onion sliced into half- moon

crescents

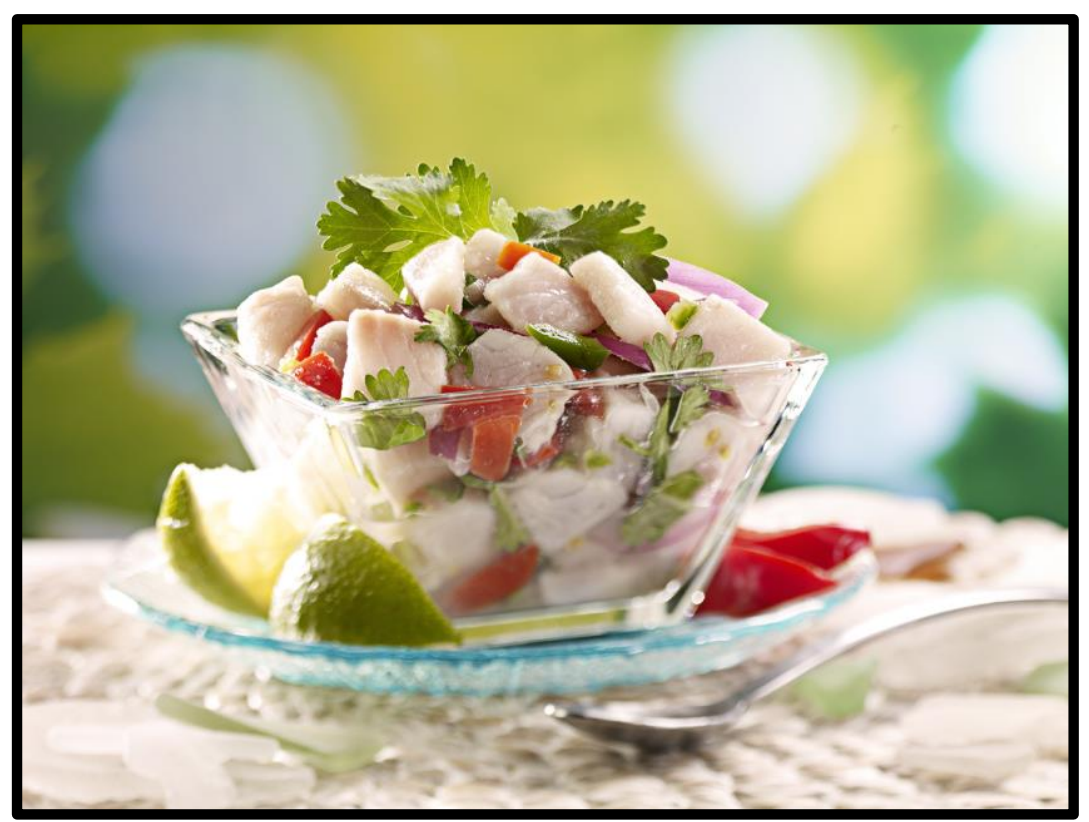

Figure 2: Ceviche (Photo Appetite, 2013)

salt and pepper

\section{To Serve:}

1 corncob, cooked and kernels removed

$1 / 2$ sweet potato, boiled and sliced

\section{Preparation:}

Cut the fish into 3/4-inch cubes, place in a bowl, and season with salt and pepper. After 1 minute, add the garlic and limo chili. Mix together well.

Pour over the lemon juice and add the chopped cilantro leaves and ice cubes. Stir and let stand for a few seconds. Add the red onion and remove the ice cubes. Mix together and adjust the seasoning to taste. Serve together in a large shallow bowl with a cooked corn kernels and boiled sweet potato slices.

\section{About the Ingredients:}

Ceviche is a common dish in Peru that consists of a type of seafood soaked in citrus and herbs 
bringing together a colorful and flavorful dish. One of Peru's beautiful regions is the long coast where seafood was a staple for some of the first recorded humans. It is unclear whether the seafood was consumed raw by some of the native tribes along the coast, but I would assume they ate some seafood raw. As for the dish itself, Japan has a similar dish called "Poke" that is raw seafood soaked in various sauces. When the Japanese migrated to Peru during the late $18^{\text {th }}$ and $19^{\text {th }}$ centuries, ceviche became more popular (Acurio, 2015). The other key ingredient in ceviche is lemon. We've learned from Chapter II that lemons were imported from Spain (Acurio, 2015). However, it is completely possible for various citrus fruits to be native to Peru. Red onions are favored in Peruvian cuisine for their intense flavor. Red onions are known from Arequipa, from Lurín, red Creole onions, and Italian red onions (Acurio, 2015, p. 421). Cilantro or "culantro" is a herb used in many Peruvian dishes (Acurio, 2015, p. 421). There are varieties of native wild cilantro that have been found in the Amazon (Native Amazon Plants [Personal interview] 2015). To serve the ceviche, it is common to have sweet potato and corn on the side. Corncob has been found in Andean roots with unusual large kernels and colors (Acurio, 2015). Additionally, sweet potatoes have been known for deep roots in Peru with orange and purple varieties (Acurio, 2015). There are many other Peruvian recipes that use these ingredients portraying a long history of use and variety. 
Pachamanca Amazónica (Acurio, 2015, p. 306)

Serves: 4

Preparation Time: 25 minutes, plus 3 hours chilling

Cooking Time: 1 hour

\section{Ingredients:}

2 medium chickens, each cut into 8 pieces

$1 / 2$ cup beef jerky or dried beef, but into bite-sized pieces

24 corn husks, for cooking $1 / 4$ cup vegetable broth 2 half ripe bellaco plantains cut into $13 / 4$ inch pieces, peel left on

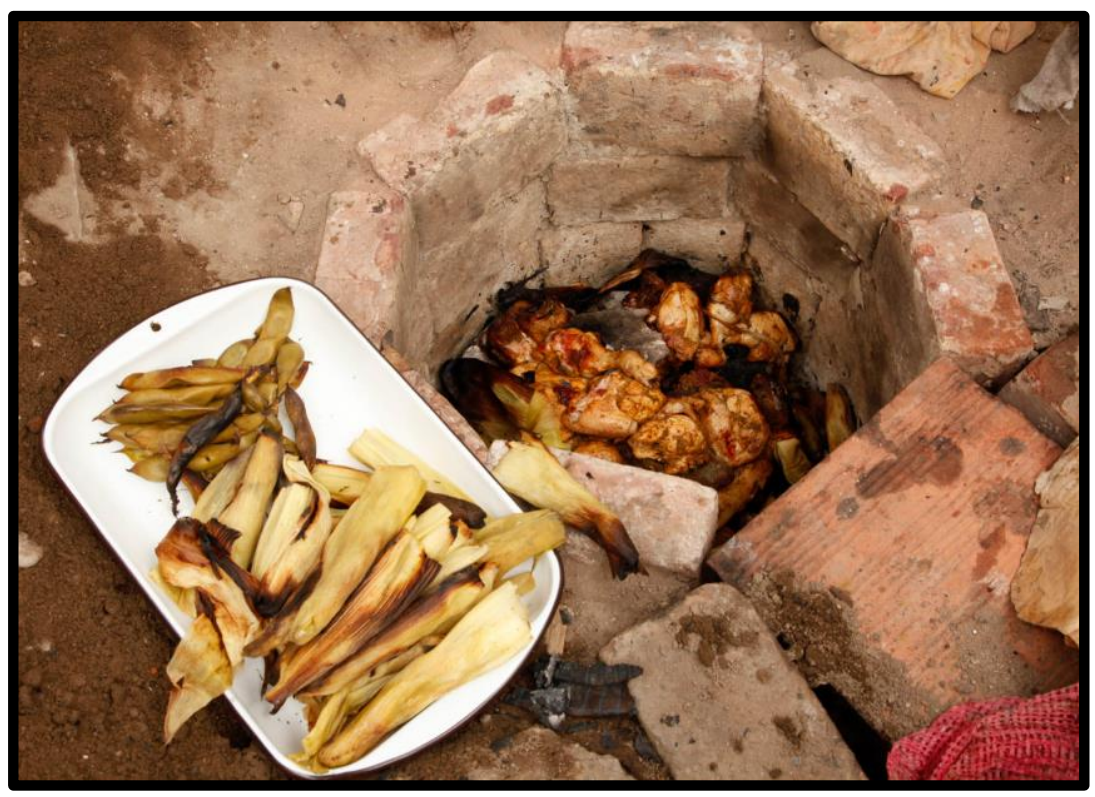

Figure 3: Cooking Pachamanca (Quinn, 2017)

$5 \mathrm{oz}$ fava beans

salt and pepper

Marinade

4 tablespoons yellow chili paste

1 tablespoon Panca chili Paste

$1 / 2$ tablespoon turmeric or chikina paste or cilantro leaves 1 sprig mint

4 Charapita chiles seeded, membrane removed and chopped 3 cloves garlic 4 tablespoon white wine vinegar

\section{Preparation:}

Put all the marinade ingredients in a blender and blend together until smooth. Tip into a bowl, add the chicken pieces and beef jerky and cover with plastic wrap. Marinate in the refrigerator for 3 hours. Next, cover the bottom of a 12 - inch earthenware pot with 12 corn husks and place the marinated chicken and beef jerky on top. Pour over the vegetable broth, add the bellaco plantain pieces and faca beans, and cover with the remaining 12 cornhusks. 
Place the lid on the pot and cook over low heat for 1 hour until the chicken is cooked through. Spoon into large shallow bowls and serve.

\section{About the Ingredients:}

Pachamanca is a traditional dish from the Amazon (Acurio, 2015). The Amazon is an "undiscovered treasure trove" that contains a new world of flavors and dishes such as Pachamanca (Acurio, 2015, p.306). Poultry was more common in dishes after the Spanish arrived. However, Pachamanca can be made with other types of meat, such as guinea pig - a common meat consumed in Peru (Acurio, 2015). Corn husks are used to wrap the ingredients. Corn is an ingredient based in North America but quickly spread to pre-Hispanic Central and South America. However, it is possible that there were other varieties such as the corn with large kernels found in the Andes that contributed to other corn varietals. The Bellaco plantain is long and thick with orange flesh and is normally boiled, roasted, or fried (Acurio, 2015). Most plantain and banana varieties are from tropical climates. It is difficult to pinpoint an origin of this plantain since I believe it came from multiple tropical parts of the world. 


\section{Aji de Gallina (Peschiera 2005 p. 64)}

Serves 6

\section{Ingredients:}

1 stewing chicken

$1 / 2$ cup vegetable oil

3 onions, finely chopped

2 cloves garlic, crushed

6 green chili peppers, seeded and pureed in a blender

8 slices of bread, crusts removed

1 cup grated Parmesan cheese

$5 \mathrm{oz}$ Swiss or Gouda cheese, cubed

$1 / 2$ lb walnuts, chopped or ground

1 can evaporated milk

6 black olives

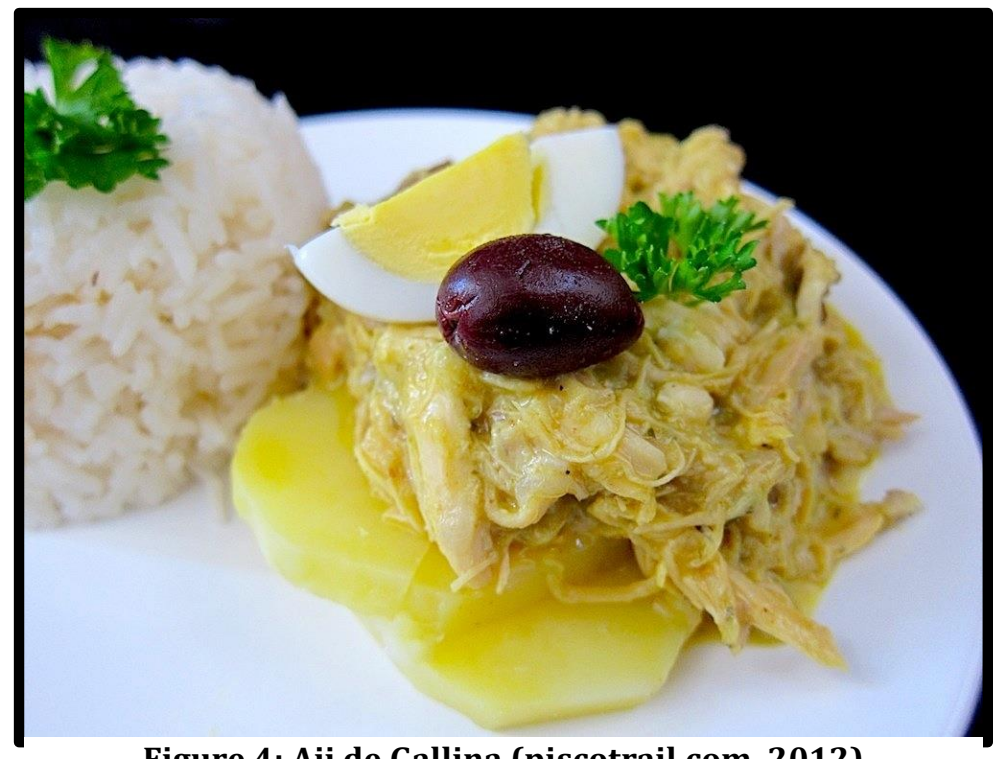

Figure 4: Aji de Gallina (piscotrail.com, 2012)

3 hard boiled eggs, quartered salt and pepper

\section{Preparation:}

Cook the chicken in salted water for at least 2 hours. Once tender, drain, cool, remove the bones and set aside. Heat the oil in a large pot and fry the onion, garlic, and pureed pepper. Soak the bread in a bit of chicken stock and add seasonings. Add the sautéed vegetables and cook 10 minutes. Add the walnuts, cheeses, and chicken. Stir well over low heat for 5 minutes until the flavors blend. Just before serving, add the evaporated milk and mix well. Serve in a large bowl or in individual dishes garnished with black olives and eggs. In Peru, this dish is traditionally served over cooked potatoes and accompanied by white rice.

\section{About the Ingredients:}

As we have learned previously, chicken was an ingredient commonly used after the Spanish arrived. This dish isn't normally used with different meat aside from chicken, so it is my 
understanding that Aji de Gallina is highly influenced from Spain. In addition, the various cheeses used are likely to come from Spain and other European influences, since the common dairy livestock didn't arrive until Spanish colonization. Furthermore, the eggs and black olives were ingredients brought from Spain. As for the chili peppers, native Peruvian peppers such as Aji Amarillo brought a melding of ingredients to the dish. This dish is primarily from Spanish influence, but there are some traces of influence from native Peruvians. It is now considered as a delicacy dish from Peru. 


\section{Chaufa (Peschiera 2005 p. 72)}

Serves: 6

Ingredients:

5 cups short-grained rice

$2 \frac{1}{4} \mathrm{lbs}$ pork loin

$5 \mathrm{oz}$ pork lard

6 eggs

1 red bell pepper, diced

1 bunch green onion, cut into fine

strips

2 cloves garlic, crushed

$1 / 2$ cup vegetable oil

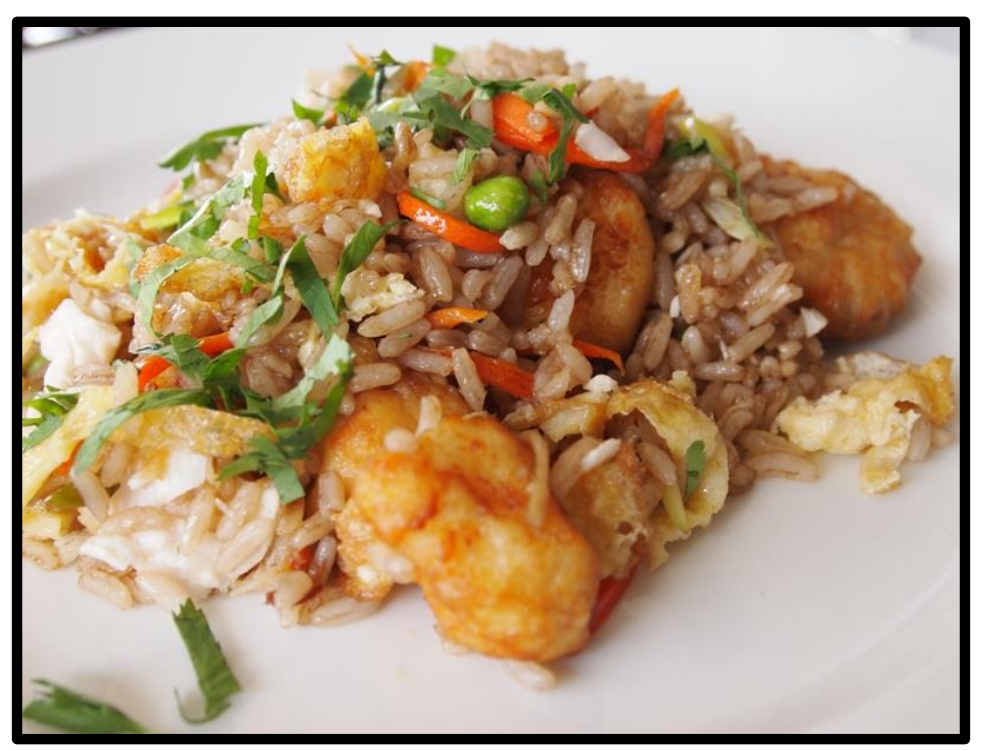

Figure 5: Chaufa (perudelights.com, 2013)

1teaspoon sesame oil

$1 / 2$ cup soy sauce

\section{Preparation:}

Cook rice as usual and set aside.

Cut the pork into $1 / 2 \times 1$-inch pieces long and brown in lard. Set aside.

In a wok or frying pan set over high heat, briefly stir-fry the pepper, green onion, and garlic.

Add the rice, omelet strips, and pork and continue stir-frying. When the ingredients are well mixed, add the soy sauce, sesame oil, and serve.

Today this dish is usually served to accompany other dishes following the tradition of the Peruvian-Chinese restaurants known as 'Chifas'.

\section{About the Ingredients:}

As we can see from the recipe, this is a dish that is stir-fried with sesame, soy, and rice.

These are ingredients commonly used in many Asian countries. This dish is primarily of 
Chinese influence during their migration in the $19^{\mathrm{h}}$ century (Acurio, 2015). We've learned from Chapter II that the culinary technique "stir-fry" is Chinese. During Chinese migration, "Chifa" - Peruvian/Chinese cuisine restaurants spread around Peru. One can walk into any Chifa restaurant and find the classic chaufa. Chaufa has become a popular dish all around Peru just the same as ceviche or aji de gallina. 


\section{Cuy}

Serves: 4

Preparation: 3 hours

Cook Time: $1 \frac{1 / 2}{2}$ hour

\section{Ingredients:}

One whole adult guinea pig, skinned, cleaned

\section{Aji \\ Preparation:}

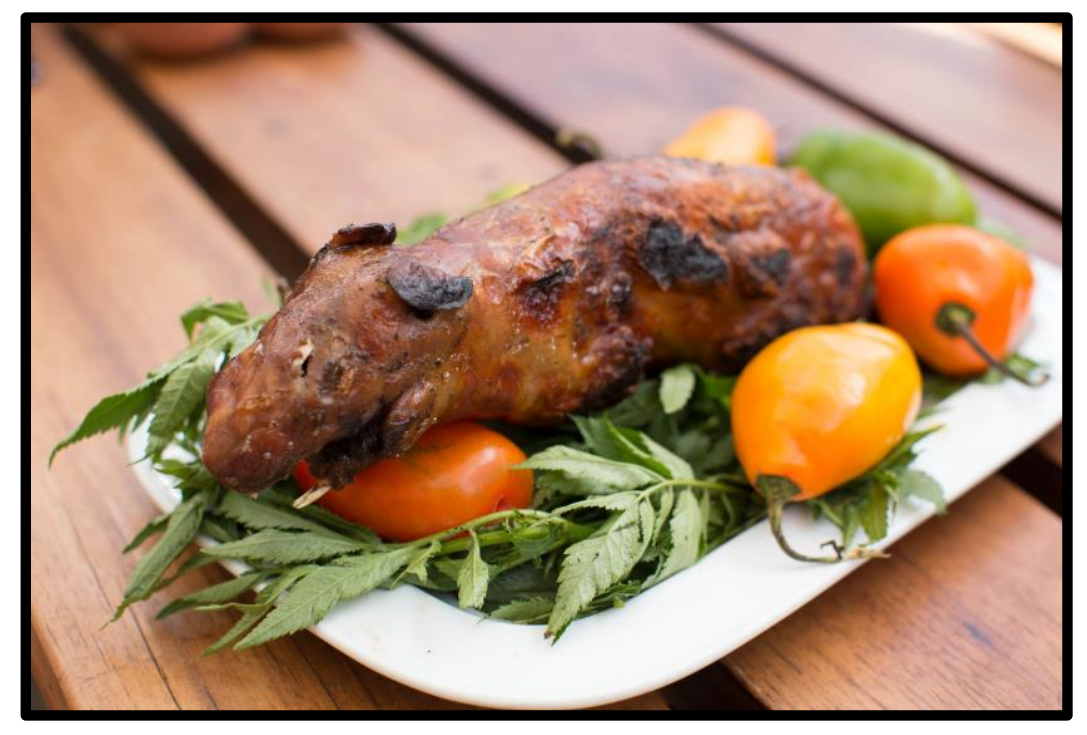

Figure 6: Cuy (lickmyspoon.com)

This is a recipe used during my

travels through Peru while working on a farm in the mountains. The owners of the farm raised guinea pigs in a pen outside their house. We killed the guinea pigs by grabbing the sides of its head and smashing it on the ground. Next, one eye was removed to drain blood. The cuy was boiled in hot water while we removed its fur. We gut the insides of the cuy saving some organs for consumption. Once it is cleaned, a 3-foot stick went through back end and out the mouth of the cuy in order to rotisserie over an open fire. The aji picante sauce is glazed over the cuy every 15 minutes until cooked through. Serve with rice cut to pieces, or whole on platter in the center. Cuy is normally served on special occasions. This occasion was my birthday, so I was served first, with addition to the honor of receiving the guinea pig heart.

\section{About the Ingredients:}

This is a native Peruvian/Ecuadorian dish. Cuy is a delicacy of Peru consisting of a fireroasted guinea pig with aji sauce spread of the top. Cuy can be found in the wild throughout the Andes. However, communities also raise the cuy in pens in their kitchens or outside 
their house to prepare as food. Cuy tend to be a lot larger than the Guinea pigs used as house pets in the United States. Eating cuy is very similar to eating a rabbit. I was lucky enough to prepare one myself and learn the traditional Peruvian Andean recipe. 
This paper analyzes the fusion of cultures into the creation of Peruvian cuisine. In Peru, people of diverse origins have come together to give rice to food recipes highly appreciated around the world. To begin, the first section revealed historical events dating back to the first human's of Peru and their diet. Before the arrival of Spaniard conquerors, Peru had multiple tribes, communities, and empires, leaving a distinct mark on the ingredients commonly used before outside influence. During the $16^{\text {th }}$ century Spain colonized Peru. Spain fused its culture into Peru bringing along connections to other European countries, the Middle East, Arab/Moorish influences, and Africa. In addition, Peru later saw the influence of Japan and China as a result of immigration in search for land and gold during the $19^{\text {th }}$ century. These historical events led to important changes in Peruvian agricultural practices, culinary techniques, and availability of newly imported foods.

The six recipes I have discussed- Pisco Sour, Ceviche, Pachamanca, Aji de Gallina, Chaufa, and Cuy- are representative of the fusion of native and global cultures that gave rise to Peruvian cuisine. As people, cultures, and countries meld together, a nation's cuisine is bound to develop until it makes a mark of its own. My limitations in this study involved tracing the origins of ingredients. Some foods, such as produce and herbs, have historically been used in many parts of the world. This made it difficult for me to trace if one ingredient was native to Peru or it was imported from another country. Meanwhile, some of my results became assumptions by observing different environments and building an understanding of what foods excel in a particular climate. I conclude, that these recipes are variations. They began as a native dish and developed through global fusion. 


\section{References:}

Acurio, Gastón. (2015). Peru: The Cookbook. London: Phaidon Limited.

Acurio, G. (2009). 500 años de fusión: la historia, los ingredientes y las nuevas propuestas de la cocina peruana. Punto y Coma Editores.

Aji de Gallina Peruana. (2012, June 3). [Digital image]. Retrieved January 17, 2017, from http://www.piscotrail.com/2012/06/03/recipes/aji-de-gallina/

Ceviche. (2013, May 30). [Digital image]. Retrieved January 17, 2017, from https://photoappetite.com/2013/05/30/ceviche/

Chaufa. (2013, August 7). [Digital image]. Retrieved January 17, 2017, from http://perudelights.com/tag/arroz-chaufa-recipes/

Cuadra, M., \& Escardó, M. (2014). The Peruvian kitchen: traditions, ingredients, tastes, and techniques in 100 delicious recipes. New York, NY: Skyhorse Publishing.

Cuy [Digital image]. (n.d.). Retrieved January 17, 2017, from https://lickmyspoon.com/travel/peru-food-and-travel-guide-cusco/

Discover the story of English More than 600,000 words, over a thousand years. (n.d.). Retrieved January 24, 2017, from http://www.oed.com/view/Entry/118135?redirectedFrom=midden\#eid

Fletcher, R. A. (2006). Moorish Spain. Univ of California Press.

Hartel, R. W., \& Hartel, A. (2008). Freeze Drying-High-Quality Food Preservation. In Food Bites (pp. 17-19). Springer New York.

Hemming, J. (1970). The conquest of the Incas. New York: Harcourt, Brace, Jovanovich.

Hudson, R. A. (1993). Peru: A country study. Washington, D.C.: Federal Research Division, Library of Congress. 
Lauer, M., \& Lauer, V. (2006). La revolución gastronómica peruana. Universidad De San Martin De porres., E. (2005). Secrets of Peruvian cuisine. Santiago, Chile: Origo Ediciones.

Lockhart, J., \& Maccormack, S. (1994). Religion in the Andes: Vision and Imagination in Early Colonial Peru. The American Historical Review,99(1), 336. doi: $10.2307 / 2166368$

Montgomery, D. (2014, August 19). Pisco Sour. Retrieved January 17, 2017, from http://professorcocktail.com/

Montgomery, D. (2014, August 19). Pisco Sour [Digital image]. Retrieved January 17, 2017, from http://professorcocktail.com/all-reviews/rum-reviews/cocktail-recipepisco-sour/

Native Amazon Plants [Personal interview]. (2015, May 22).

Peterson, J. B., \& Soltvedt, B. (2006). Eat Smart in Peru: How to Decipher the Menu, Know the Market Foods and Embark on a Tasting Adventure. Ginkgo PressInc.

Quinn, K. (n.d.). Pachamanca [Digital image]. Retrieved January 17, 2017, from http://www.seriouseats.com/2014/10/peruvian-pachamanca-earth-oven-partyfood.html

Takenaka, A. (2004). The Japanese in Peru: History of Immigration, Settlement, and Racialization. Latin American Perspectives, 31(3), 77-98. Retrieved from http://www.jstor.org.proxy.lib.pdx.edu/stable/3185184

Tannahill, R. (1973). Food in history. New York: Stein and Day.

Zarate, R., \& Garbee, J. (2015). The fire of Peru: recipes and stories from my Peruvian kitchen. Boston: Houghton Mifflin Harcourt. 